\title{
The (Non)sense of the Present-Day Classification System of Sports for the Disabled, Regarding Paralysed and Amputee Athletes
}

\author{
M. D. F. van Eijsden-Besseling \\ Dutch Sportsorganization for the Disabled (N.I.S.), P.O. Box 622, 3800 AP \\ Amersfoort, The Netherlands.
}

\section{Summary}

In order to guarantee fair competition amongst athletes, suffering from spinal paralysis with different neurological levels, a classification-system on a medical basis was introduced at the beginning of the annual Stoke Mandeville Paraplegic Games in the 1950s. The system was set up in such a way, that athletes with comparable degrees of disability were put together in the same class, in principle not depending on the actual sporting events. Subsequently a similar system was introduced for amputee athletes, and this system is still being used.

In view of the large number of competitors, the Olympic Games for the Disabled in 1980 in the Netherlands were the basis for a statistical research analysis on the acquired data, studying the results of competition in connection with the medical classification data.

The following types of sports were looked at: athletics, swimming, archery and weight-lifting. The objective was, to justify the (theoretical) medical classificationsystem by means of (practical) actual figures (results of competition). As a basic method the 'zero-hypothesis' has been used. Specifically the 'Student's $t$ distribution' has been used in view of the small samples. The interim conclusion is, that the present-day classification-system is good with regards to those with poliomyelitis, and to tetraplegic and paraplegic sports people both with complete or incomplete lesions competing together, but the number of classes requires to be diminished in several sports events. The same research analysis of the results of the Olympic Games for the Disabled of 1984 will be made in order to compare the two studies and to make final conclusions.

Key words: Sports for the disabled; Handicap categories/classes; Classification system; Statistical analysis; Results of competition. 


\section{Introduction}

In sport for the disabled, those participating, depending on their handicap, are classified into various categories and subsequently in classes to guarantee fair competition; the so-called classification-sytem (see Appendix for Key to Classification System used in Tables).

About 1980 the participants themselves and the technical officers let it be known, that the classification-system should be modified. The basic question raised, was: 'Is it necessary that the categories are subdivided into so many classes?' Because, the greater the number of classes, the less will be the competitive element. The most important object of this research therefore was: 'Is it justified, from the statistical point of view, to have all these classes, taking into account the results of competition, or should they be allowed to join the classes?'

A second question was: 'Is it permissible in the category of the paralysed to join para-/tetraplegics with those with poliomyelitis in the competition as well as those with incomplete and with complete lesions' (as it happens now).

\section{Material and methods}

In view of the large number of competitors, the Olympic Games for the Disabled of 1980 in the Netherlands, were the basis for a statistical research analysis on the acquired data comparing the results of competition in relation to the medical classification data. The categories of the paralysed (tetra/paraplegics, polio's) ( \pm 1000 athletes) and amputees ( \pm 400 athletes) were looked at, and the following sports were considered: athletics, swimming, archery and weight-lifting. The results of competition have been statistically analysed by using the 'zero-hypothesis'.

The 'Student's $t$ distribution' has been used in view of the small samples. The significance level has been chosen equal to $0 \cdot 05$.

The following hypotheses have been worked out.

1. In the category of the paralysed, there is no significant difference in results between polio's and tetra-/paraplegics in a certain class related to a certain sports event. (Both males and females were considered).

2. In the category of the paralysed, there is no significant difference in results between incomplete and complete lesions in a certain class related to a certain sports event. (Both males and females were considered).

3. If the hypotheses 1 and 2 are accepted, then all the classes involved in the same sports event can be compared with each other regarding the category of the paralysed. The hypothesis may then be formulated as follows: there is a significant difference in results among the several classes involved in the same sports event. (Both males and females were considered).

The same hypothesis can be formulated when comparing classes of the amputee category with each other. There is a significant difference in results among the several classes involved in the same sports event (Both males and females were considered). 


\section{Results}

In all cases considered, hypothesis 1 and 2 were accepted in the category of the paralysed. As a result hypothesis 3 could be worked out. In most of the cases hypothesis 3 was rejected, both in the category of the paralysed and the amputees. That means, that a lot of classes can be combined in competition.

Example: category of the paralysed

Sport: swimming female/male

possible combination of classes

\begin{tabular}{lll}
\hline & \multicolumn{1}{c}{$\mathrm{F}$} & \multicolumn{1}{c}{$\mathrm{M}$} \\
\hline 25 m breaststroke & $1 \mathrm{~A}, 1 \mathrm{~B}, 1 \mathrm{C}$ & $1 \mathrm{~A}, 1 \mathrm{~B}$ \\
50 m breaststroke & 2,3 & 2,3 \\
100 m breaststroke & $4,5,6$ & $4,5,6$ \\
25 m backstroke & $1 \mathrm{~A}, 1 \mathrm{~B}, 1 \mathrm{C}$ & $1 \mathrm{~A}, 1 \mathrm{~B}, 1 \mathrm{C}$ \\
50 m backstroke & & 2,3 \\
100 m backstroke & $4,5,6$ & $4,5,6$ \\
25 m freestyle & $1 \mathrm{~A}, 1 \mathrm{~B}, 1 \mathrm{C}$ & $1 \mathrm{~A}, 1 \mathrm{~B}, 1 \mathrm{C}$ \\
50 m freestyle & 2,3 & 2,3 \\
100 m freestyle & $4,5,6$ & 4,5 or 5,6 \\
25 m butterfly & $2,3,4$ & $2,3,4$ \\
50 m butterfly & 5,6 & 5,6 \\
$4 \times 50$ m individual medley & $4,5,6$ & 5,6 \\
\hline
\end{tabular}

(See Tables in appendix for detailed information).

The interim conclusion is, that the present-day classification system is correct with regard to polios and tetra-/paraplegics as well as incomplete and complete lesions competing together in the category of the paralysed. However, the number of classes has to be reduced in several sports events in the category of the paralysed as well as in the amputee category.

\section{Discussion}

The research analysis was unfortunately negatively influenced by:

1. The subjective judgement of any doctor involved in classifications.

2. Badly completed classification forms (missing data).

3. Not measurable training effects.

4. Small samples.

5. As yet there are no fixed limits of performance of participation.

However, it was possible to a certain extent, to eliminate points 2,4 and 5 in the Olympic Games for the Disabled in 1984 in America.

It is important to make the same research analysis on the data of the Olympic Games for the Disabled in 1984, as has already been started, and to compare both analyses with each other to make a final conclusion.

It is worth mentioning that nowadays, fortunately, the classification for 
the specific sport, that the athlete takes part in, is considered more closely.

Therefore the results of the statistical research analysis from the data of the Olympic Games for the Disabled of 1984 will require to be interpreted especially in relation to the kinesiological elements specific to each sport.

Exceptions to the present-day classification system:

A. In the category of the paralysed some classes already compete together, i.e.

- in archery tetraplegics as well as paraplegics already compete together.

— in athletics, class 5 and 6 already compete together (see Table 1 in Appendix).

- in weight lifting the classes compete together but athletes are classified by their bodyweight

From the statistical point of view this situation appears to be correct.

B. In the category of amputees some classes also already compete together, i.e.

- in swimming

- in archery all the classes compete together

- in weight lifting the classes compete together, and athletes are classified by their bodyweight.

From the statistical point of view also this situation appears to be correct.

\section{Résumé}

Afin de garantir des compétitions équitables parmi les athlètes souffrant de paralysie provoquée par des lésions à la moelle épinière, à différents niveaux neurologiques, une classification sur base médicale avait déja été introduite au début des jeux annuels de Stoke Mandeville dans les années 50 .

Le système avait été élaboré de telle façon que les athlètes handicapés à des degrés comparables avaient été placés dans la même classe, en principe, indépendamment de leur sport. Plus tard, un système similaire a été introduit pour les athlètes amputés. Ce système est toujours en application. Le grand nombre de données recueuillies au cours des jeux Olympiques de 1980 aux PaysBas, a permis de les soumettre à une analyse statistique. L'objectif était de découvrir si les performances sportives des athlètes handicapés moteur sont en fonction de leur classification.

Les sports suivants ont été pris en considération: athlétisme, natation, tir à l'arc, poids et haltères.

L'hypothèse zéro a été appliquée et en raison du petit nombre des participants la méthode de 'Student's $t$ distribution' fut choisie. La conclusion provisoire est que le système de classification actuel est valable si les athlètes qui se mesurent entre eux sont handicapés par suite de polio, de tetraplégie, de paraplégie ét est valable si les athlètes qui se mesurent entre eux sont handicapés par suite de lésions complètes et incomplètes, mais qu'il faut restreindre le nombre des classes dans un certain nombre de rencontres sportives. Les données des jeux Olympiques pour des handicapés de 1984 seront soumises à une même analyse que celles de 1980, après quoi une comparaison de ces deux analyses permet de formuler une conclusion définitive.

\section{Zusammenfassung}

Damit ein ehrlicher Wettbewerb zwischen Sportler mit Rückenmarklähmungen auf unterschiedlichen neurologischen Niveaus, gewährleistet wird, wurde eine Klassifizierung nach medizinischen Masstäben bereits eingeführt beim Anfang der jährlichen Stoke Mandeville Spiele in den fünfziger Jahren. Das System wurde so ausgebaut, dass Sportler mit vergleichbarem Behinderungsgrad in die gleiche Klasse eingeteilt wurden, grundsätzlich unabhängig von ihrem Sportzweig.

Später wurde ein ähnliches System eingeführt für Sportler mit einer Amputation. Dieses System wird noch immer angewandt. Wegen der grossen Anzahl Teilnehmer waren die Olympischen Spiele für Behinderte 1980 in den Niederlanden die Basis für eine statistische Analyse der erhaltenen Daten, b.z.w. Wettkampfergebnisse im Zusammenhang mit den medizinischen Klassifizierungsdaten. 
Die Sportarten Athletik, Schwimmen, Bogenschiessen und Gewichtheben wurden mit in die Untersuchung hineingezogen. Die Absicht war die jetzige (theoretische) medizinische Klassifizierung zu bewerten an Hand der Daten aus der Praxis (Wettkampfergebnisse).

Die Null-Hypothese wurde gebraucht zugeschnitten auf die Student's $t$-Verteilung, mit Rücksicht auf die geringe Anzahl Sportler in bestimmten Klassen.

Die vorläufige Schlussfolgerung ist dass die jetzige Klassifizierung richtig ist, was das zusammen Sport betreiben betrifft von Polio-Teilnehmern mit Querschnittgelähmten Teilnehmern und von unvollständig mit vollständig Gelähmten, aber dass die Anzahl Klassen in verschiedenen Sportzweigen herabgesetzt werden kann.

Jetzt wird die gleiche statistische Analyse der Wettkampfergebnisse dieser Olympischen Spiele 1984 gemacht werden. Die Absicht besteht die beiden Analysen 1980 und 1984 dann miteinander zu vergleichen, damit eine endgültige Schlussfolgerung gezogen werden kann.

\section{References}

Classification forms of the paralysed and amputee athletes, Arhheim, 1980.

HoEL PG 1966 Elementary statistics, John Wiley and Sons, Inc; New York, p. 172-177.

I.S.M.G.F. 1982 Guide for doctors, Stoke Mandeville, Aylesbury, England, p. 6-17.

I.S.O.D. Handbook 1981 Classification code for amputees; section 1, ch 4, p. 1.4.1 Farsta.

Sijtsema WY, RÜCKert HJ 1977 'Meedoen is Winnen', 2nd edn, Hengelo, p. 29-33.

\section{Appendix}

Key to classification system used in Tables 1 and 2 for the paralysed.

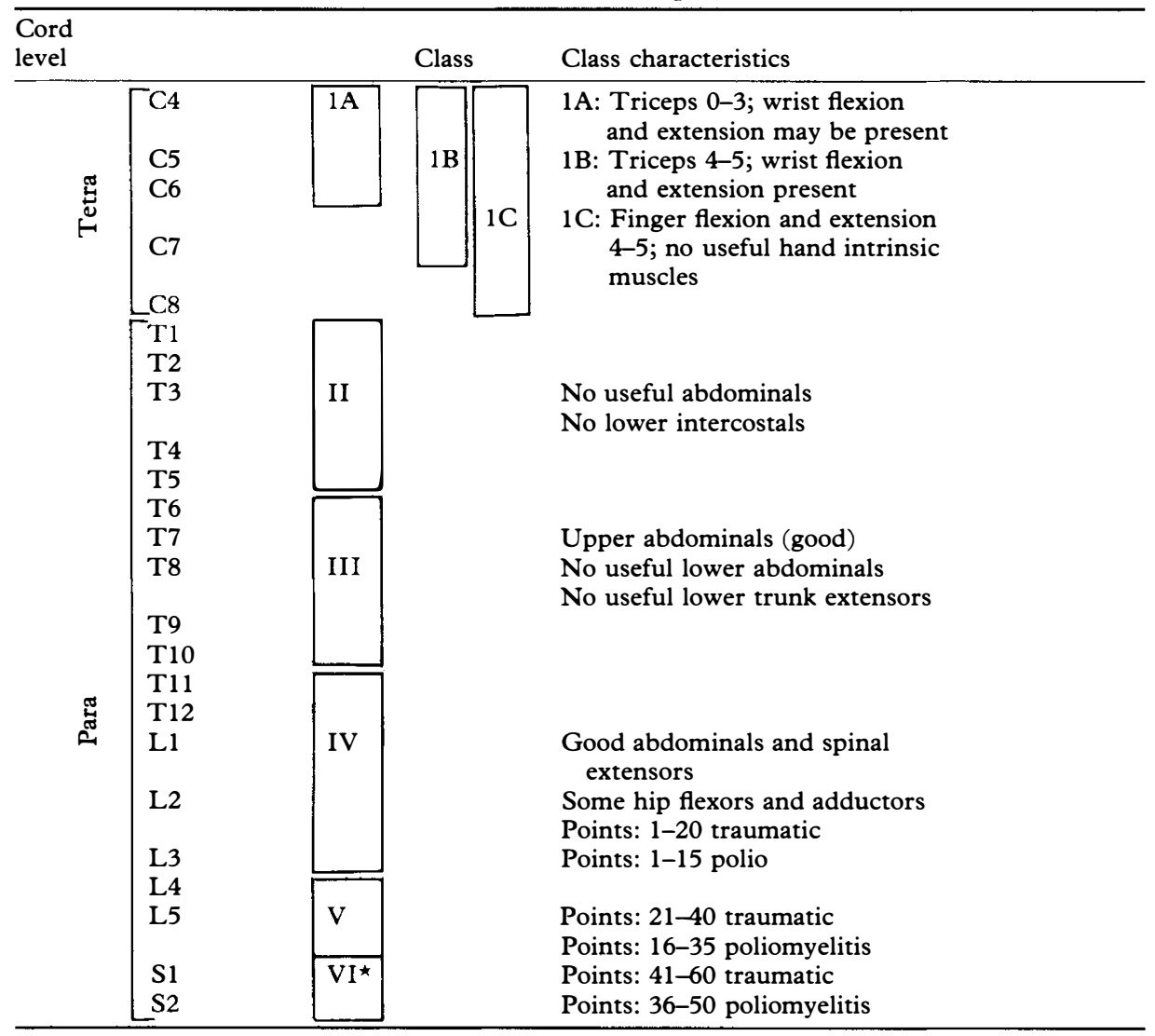

Not eligible.

Traumatic 61 points and above/Polio 51 points and above.

*Class VI is a 'subdivision' of class V applied in swimming and athletics only.

Points are muscle grades, testing on the $0-5$ scale. 


\section{Summary of conclusions}

Table 1

Category: Tetra/Para/Polio
Classes

Table 2

Category: Tetra/Para/Polio

Sport: Swimming

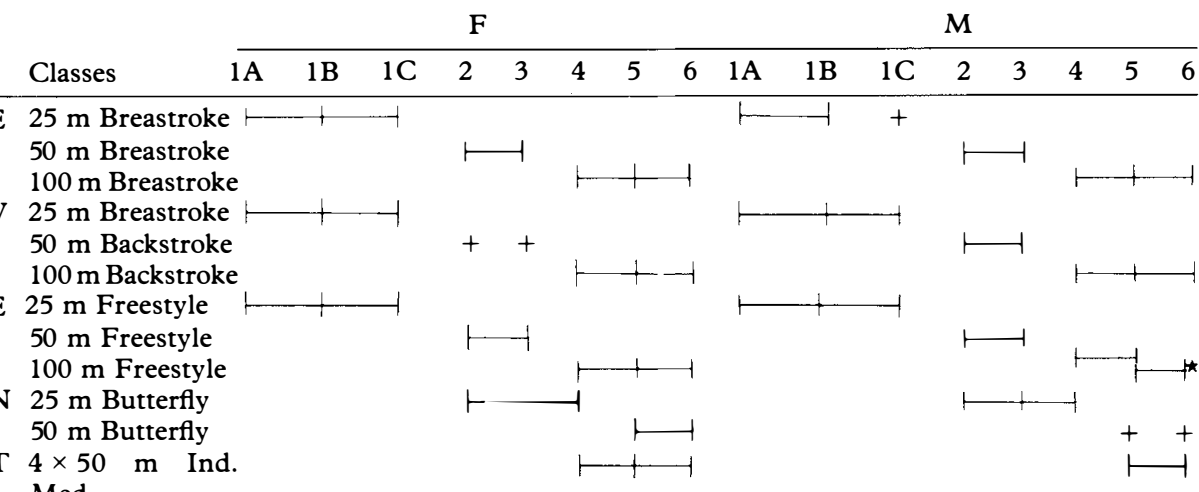

$|-|-\mid=$ The vertically marked classes on a line form the possible combinations.

$\star=$ Preferable combinations from the statistical point of view.

$+=$ No combination possible.

Blanks $=$ No entry.

Key to classification system in Tables 3 and 4 for amputees

Class $\mathrm{A} 1=$ double above knee amputation.

Class A2 = single above knee amputation.

Class A $3=$ double below knee amputation.

Class A4 = single below knee amputation.

Class A5 = double above elbow amputation.

Class A6 = single above elbow amputation.

Class A7 = double below elbow amputation.

Class A8 = single below elbow amputation.

Class A9 = combined lower plus upper limb amputation. 
PARAPLEGIA

\section{Summary of conclusions}

Table 3

Category: Amputees
Classes

Table 4

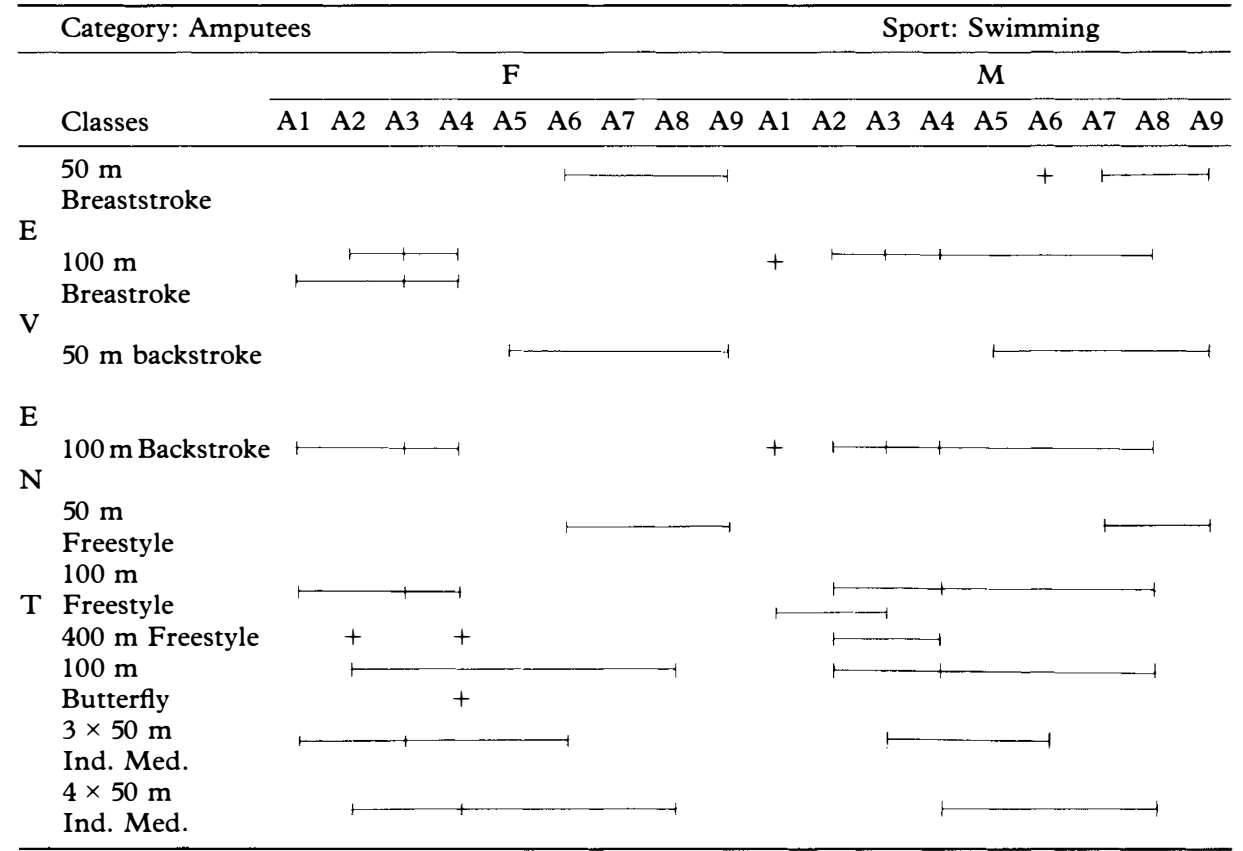

$|-|=$ The vertically marked classes on a line form the possible combinations. $+=$ No combination possible.

blanks $=$ No entry. 